\title{
Demystifying Negative Connotations of Hybridization for Less Biased Conservation Policies
}

\author{
David Draper ${ }^{1,2 *}$, Emilio Laguna ${ }^{3}$ and Isabel Marques ${ }^{1,4 *}$ \\ ${ }^{1}$ Centre for Ecology, Evolution and Environmental Changes (CE3C), Universidade de Lisboa, Lisbon, Portugal, ${ }^{2}$ Department \\ of Botany, University of British Columbia, Vancouver, BC, Canada, ${ }^{3}$ Centro para la Investigación y Experimentación Forestal, \\ Servicio de Vida Silvestre e Generalitat Valenciana, Valencia, Spain, ${ }^{4}$ Plant-Environment Interactions and Biodiversity \\ Laboratory (PlantStress and Biodiversity), Forest Research Centre (CEF), Instituto Superior de Agronomia (ISA), Universidade \\ de Lisboa, Lisbon, Portugal
}

OPEN ACCESS

Edited by:

J. Guy Castley,

Griffith University, Australia

Reviewed by:

John Thompson,

UMR 5175 Centre d'Ecologie Fonctionnelle et Evolutive (CEFE),

France

Gonzalo Nieto Feliner, Real Jardín Botánico (RJB, CSIC),

Spain

Claudio Sebastián Quilodrán, Université de Genève, Switzerland

*Correspondence: David Draper ddmunt@gmail.com Isabel Marques isabel.ic@gmail.com

Specialty section: This article was submitted to Conservation and Restoration Ecology,

a section of the journal Frontiers in Ecology and Evolution

Received: 02 December 2020 Accepted: 14 April 2021

Published: 07 May 2021

Citation:

Draper D, Laguna E and Marques I (2021) Demystifying Negative Connotations of Hybridization for Less Biased

Conservation Policies.

Front. Ecol. Evol. 9:637100. doi: 10.3389/fevo.2021.637100
Interspecific hybridization is one of the most controversial-and usually neglectedissues in conservation due to its multiple evolutionary consequences that might include the origin and transfer of adaptations, the blur of distinctive lineages or the formation of maladaptive hybrids. However, despite different outcomes, most conservation laws do not offer any possibility of hybrids being protected since they are perceived as a threat to the survival of pure species. We assessed how much hybridization has contributed to species extinction considering all IUCN Red Data assessments. However, we found that it has been scarcely reported as a threat contributing to extinction: only 11 extinct species out of 120,369 assessments mentioned hybridization. Although the causes that contribute to species extinctions should be controlled, the reasons for not conserving hybrids seem subjective rather than empirically supported. In a genomic era where hybridization is being more frequently detected, the debate involving the conservation of hybrids should be re-opened. Should we conserve hybrids despite the possibility of gene flow with parental species? Should we protect only natural hybrids? The resolution of this debate goes to the heart of what we mean to conserve and the time scale of conservation. But hybridization is part of the evolutionary process and might even increase in the future due to human-induced changes. As such, it becomes clear that we need to move beyond the causes and instead tackle the consequences of hybridization to create environmental policies for the management of hybrids, considering both positive and negative consequences.

Keywords: hybrids, species extinction, conservation, environmental policies, habitat threats

\section{HYBRIDIZATION: A COMPLEX CONSERVATION TOPIC}

The old debate proclaiming hybridization as an irrelevant phenomenon of little or no evolutionary importance has been largely contested by accumulated evidence showing that hybrids are not always rare, nor the evolutionary consequences of hybridization negligible (Mayr, 1940, 1942; Dobzhansky, 1951; Rieseberg, 1997; Grant and Grant, 1998; Arnold, 2006; Mavárez et al., 2006; Abbott et al., 2010; Yakimowski and Rieseberg, 2014). Several studies have shown that hybridization 
could be a threat to the long-term persistence of scarce or endangered species through assimilation or outbreeding depression, which has led to the predominant negative view that interspecific gene flow may contribute to the extinction of species through direct and indirect means (Ellstrand, 1992; Rhymer and Simberloff, 1996; Rieseberg and Carney, 1998; Levin, 2002). Because of this, hybrids have been neglected in conservation and environmental policies as they are seen as a threat to pure species.

We now know that interspecific hybridization occurs in a wide variety of organisms, with plants being well cited examples (Mallet, 2008, 2005; Soltis and Soltis, 2009; Vallejo-Marín and Hiscock, 2016; Nieto Feliner et al., 2017). In total, 5.6\% of all plants in the Mediterranean region are estimated to be hybrids although these numbers rise in well-studied regions such as the Iberian Peninsula where $12.7 \%$ of all reported plants are hybrids (Marques et al., 2018). These quantifications are mostly underestimations as they only consider hybrids that are reported in floras based on morphological and distributional evidence. In fact, new sequencing technologies are showing the occurrence of interspecific gene flow in a wide number of lineages, including animals and fungi where hybridization was once thought to be rare (Albertin and Marullo, 2012; Twyford and Ennos, 2012; Gramlich et al., 2018; Irisarri et al., 2018). Altogether the breath of temporal and spatial contexts at which natural hybridization occurs (Abbott et al., 2013) and the frequency of this phenomenon in the living world (Mallet, 2005) implies that conservation policies should be updated, taking into consideration the diversity of situations and outcomes of hybridization. In a changing environmental scenario, hybrids could be of great importance as reservoirs of genetic diversity (Allendorf et al., 2001; Quilodrán et al., 2020) and hybridization might be an evolutionary rescue for less adapted species, although this issue remains controversial (Stelkens et al., 2014; Charles and Stehlik, 2020).

\section{LEGAL AND CONSERVATION FRAMEWORKS CONCERNING HYBRIDIZATION}

Early conservation policies overlooked any potential benefit in promoting the protection of hybrids. The United States Endangered Species Act (ESA) was strongly against the protection of hybrids since it could hinder the recovery of endangered species (US, 1973; USFWS and NOAA, 1996; Haig and Allendorf, 2006). Paradoxically, it was famously pointed out that two of the ESA's flagship species, the Florida panther and the red wolf, would not be protected under this law due to their hybrid origin (O'Brien and Mayr, 1991). The ESA has been amended several times but to this day, it has been silent in relation to the conservation of hybrids (Erwin, 2017). The Canadian Species at Risk Act (SARA) considers anthropogenic hybrids a threat to parental species and advise their eradication, except if the hybrid can supplement the genetic diversity of depauperate populations (SARA, 2002; COSEWIC, 2008). In general, United States and Canadian policies have the potential to promote hybrid conservation but only under a narrow set of circumstances that are not well defined, with the protection of hybrids clearly overlooked (Piett et al., 2015).

The European Union 1992 Directive on the Conservation of Natural Habitats and of Wild Fauna and Flora (Habitats Directive), which serves to implement the Bern Convention within the EU (Council Directive 92/43/EEC), aims to promote the maintenance of biodiversity but also has no detailed guidelines toward wild hybrids either. From the text of the provisions in the Bern Convention, contracting parties should ensure the protection of the species involved, which could mean preventive and mitigation actions including the removal of hybrid specimens from the wild. But those provisions also imply that wild-born hybrid specimens could have a protection requirement in countries where parental species are to be protected (Trouwborst, 2014), which seems contradictory.

The major global authority in conservation and the measures needed to safeguard it-The International Union for the Conservation of Nature-considers hybridization as a criterion that supports taxa reduction at the same level of pathogens, pollutants, competitors, or parasites (criterion A: IUCN, 2020a. Standards and Petitions Committee 2019), being classified as threats for the survival of species (threat 8.2.2: IUCN, 2020d). This means that evaluators of the extinction risk of species might declare hybridization as a threat even without a specific quantification of its impacts. Furthermore, it is specifically stated that hybrids should not be treated as pure species and therefore cannot be elected for Red List assessments. An exception is made for apomict plant hybrids ${ }^{1}$ although, ironically, all formed "clones" from apomictic plants can still grow vigorously and displace other plants (Carman, 1997; Hojsgaard and Hörandl, 2019).

Overall, hybrids are either neglected in legal frameworks or considered a threat to conservation goals.

\section{HOW MANY SPECIES WENT EXTINCT BECAUSE OF HYBRIDIZATION?}

We have tackled this question using the 120,369 global species assessments available on the IUCN Red List Data (IUCN, 2020c). These assessments evaluate the chances of extinction, prioritize actions and identify the major threats for species survival. Because hybridization is stated as a threat by IUCN we assumed its prevalence on a high number of assessments. However, from the 120,369 global IUCN Red List assessments, only 1,237 of them mentioned hybridization, being distributed in three different phyla: Chordata (520 assessments), Tracheophyte (344 assessments) and Cnidaria (294 assessments) (Figure $\mathbf{1}$ and Supplementary Table 1). This implies that hybridization was considered a threat in only $0.8 \%$ of IUCN assessments. The frequency of reports mentioning hybridization was even lower $(0.56 \%)$ if considering only threatened categories, i.e., Vulnerable, Endangered or Critically Endangered species (Figure 1). In relation to extinct species, hybridization was mentioned on 11 evaluations of extinct species (Figure 1 and

\footnotetext{
${ }^{1}$ https://www.iucnredlist.org/resources/tax-sources
} 
Supplementary Table 1) from a total of 959 extinct species (EX and EW) reported in IUCN (2020c). Numbers within IUCN might even be lower because hybridization is not categorized independently in the classification scheme of IUCN threats since it also includes harmful plants, animals, or pathogens and other microbes (IUCN, 2020d: threat 8.2.2). However, we also queried the IUCN Red List for reports that stated hybridization as a stress to species survival (rather than a threat), but we only found 81 assessments (threat 8.2.2 and stress 2.3.1; IUCN, 2020d,b, respectively) representing $0.07 \%$ of all cases. Altogether, the results showed that hybridization has been involved in species extinctions less often than thought.

Although hybridization might have negative consequences and species extinctions should be prevented, detailed studies documenting threats by genetic assimilation are complex and scarce (Chan et al., 2006). For instance, hybridization has been reported to be involved in the local extinction of two wild radish species due to the formation of a very successful lineage (Hegde et al., 2006). A similar situation is reported to have occurred in Spartina after hybridization between native and invasive species although all hybrids were subsequently eradicated (Ainouche et al., 2003; Ayres et al., 2009). Revisitation of certain case studies with new tools also exemplify the difficulty of documenting ongoing interspecific gene flow. For instance, new genomic evidence failed to support the hybrid origin of Helianthus bolanderi as reported decades ago, rather finding evidence for introgression into the invader H. annuus (Owens et al., 2016).

But what are the biological or ethical reasons for not conserving hybrids? Non-polyploid hybrid speciation usually occurs along a long evolutionary time frame. When hybrid speciation is completed, reproductive isolation normally prevents hybrid species from backcrossing. At intermediate stages of the process, however, there might be a risk of introgression or genetic assimilation of parental species, especially rare ones, if they come into contact (Rieseberg and Carney, 1998). However, they would not be more of a threat than other closely related species capable of mating with that species. Genetic assimilation can also go both ways, and those "intermediate hybrids" might easily be swapped by well-established parental species.

\section{WHERE DO WE STAND IN THE FUTURE OF HYBRIDS IN CONSERVATION OR ASSESSMENT LISTS?}

Hybridization occurs in nature and is part of the evolutionary process. In the wide set of impacts of global change on biodiversity, it seems clear that hybrids should neither be neglected, nor should they all be selected for protection. However, there has been little progress in advancing this issue. In what circumstances should hybrids be considered a threat?

Several scientific guidelines have been published to help policy makers optimize conservation efforts by considering the different outcomes of hybridization and setting guidelines that suggest whether hybrid conservation is beneficial but also ethical (Allendorf et al., 2001; Jackiw et al., 2015). However, they usually start with documenting the causes of hybridization (i.e., natural, or anthropogenic) which is unknown in most cases. Quantifying thresholds of hybridization and defining the minimum data needed to determine a hybrid have been proposed as strategies to improve guidelines for Red Lists (Hayward et al., 2015). However, using a "pure species concept" for the conservation of species is not possible in most cases due to insufficient information and to the fact that there are many known species that hybridize with congeners (Rhymer and Simberloff, 1996). For instance, the degree of hybridization between the Przewalski's and the domestic horse throughout its entire population is well known and yet this has not stood against its legal protection (Clark et al., 2006) being on the IUCN Red List (King et al., 2015) and even listed on CITES Appendix $I^{2}$. There is also a difference between species of hybrid origin that are now clearly isolated from parental species (Marques et al., 2016) and intermediate stages where hybridization is ongoing being hybrids not yet named although they still enhance diversity (Thompson et al., 2010, 2018).

Overall, the bias against the conservation of natural hybrids has no logical framework and the "precautionary principle" which underpins species conservation has been overruled in cases of hybrids, see Hayward et al. (2015). For instance, in updated versions of the Spanish Red Book of threatened plants (Moreno, 2008), some species were delisted just because they were found to be hybrids. Another delisting example was the Critically Endangered kouprey (Bos sauveli) a species previously listed as on the verge of extinction that was later considered a feral hybrid after a genetic study (Galbreath et al., 2006). The fact that IUCN specifically recommends that hybrids should not be protected is a support for the conservation of pure species. A solution would be to simply remove this sentence from the guidelines.

Considering the large evidence supporting the presence of hybrids, the debate dealing with the conservation of hybrids should be re-opened. For instance, should we conserve only hybrids isolated from progenitor species? And how should we regard rare hybrid species formed between introduced and native species? At a first glance, only hybrids produced by natural hybridization would be cases for positive conservation policy for hybrids. Yet, what would then happen with the Florida panther that has been bred intentionally with an introduced species for genetic rescue? This poses a dilemma especially considering that hybridization resulted in increased population levels, colonization of new areas and improvement of its demographical trend (Pimm et al., 2006).

How should we deal with recombined hybrids or cases where subsequent polyploidy has given rise to stable lineages as Senecio cambrensis and S. eboracensis in the British Isles (Lowe and Abbott, 2004; Abbott et al., 2009)? These hybrids originated from natural hybridization involving an introduced species (Senecio squalidus-itself a hybrid species originally from Mount Etna, Sicily) that escaped from cultivation in the Oxford Botanic Garden (United Kingdom) in the late 18th Century (Abbott et al., 2009). The spread of S. squalidus throughout the British Isles has resulted in novel hybridization events with native Senecio species which gave rise to new fertile hybrid taxa (Abbott and Lowe, 2004). None is protected and yet some are no

${ }^{2}$ https://cites.org/eng/node/21439 


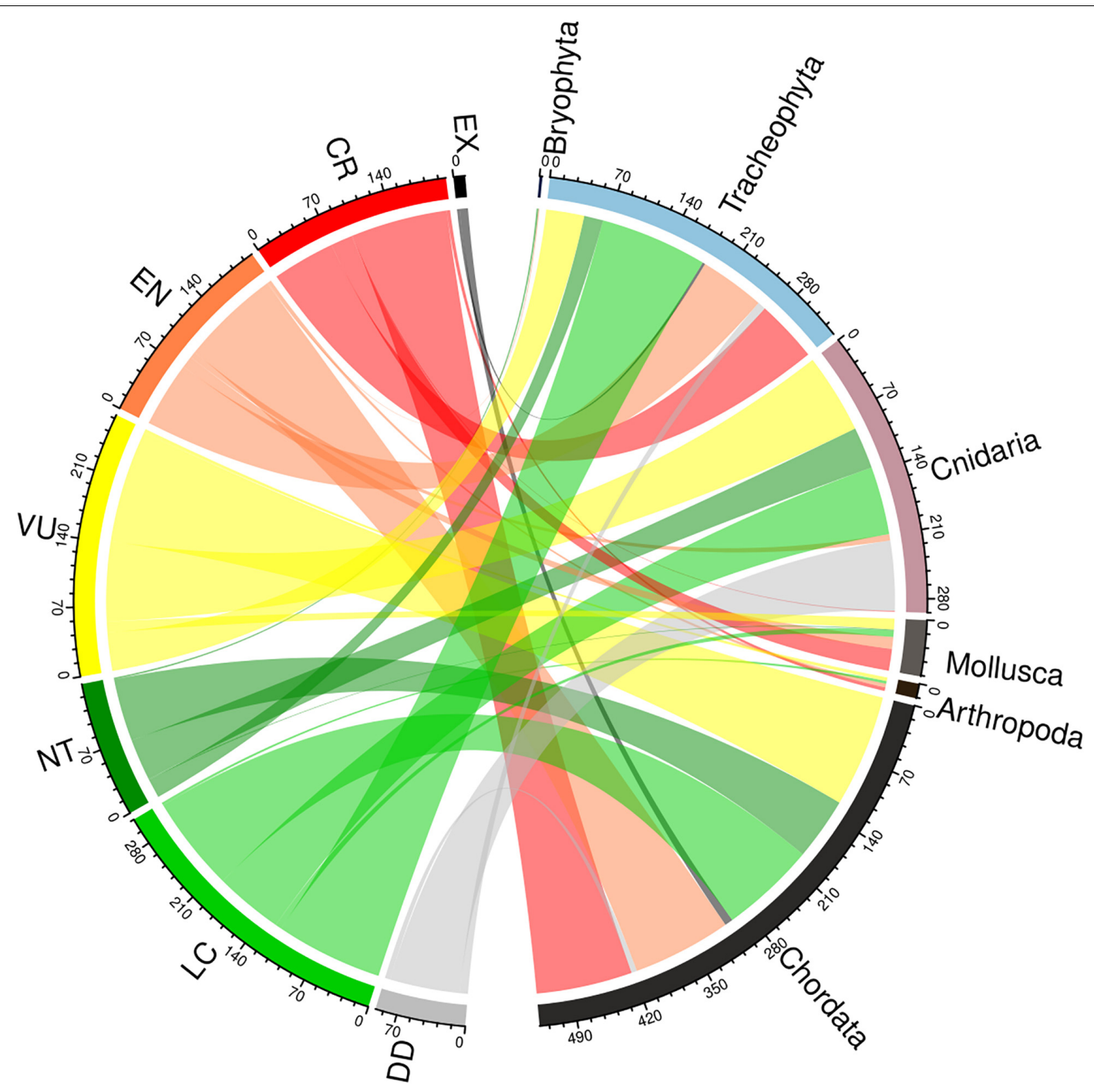

FIGURE 1 | Number of IUCN assessments per Categories where threat 8.2.2 is referred (left) related to the phyla (right) based on data from the IUCN Red List (IUCN, 2020c). EX category includes EW, NT include LR/nt and LC includes LR/lc and LR/cd. Five Fungi assessments also include this set but are not represented in this plot (chord diagram created using the circlize package in R by Gu et al. (2014).

longer found, while others have conservation problems. After more than 200 years of naturalization should these hybrids be considered for protection? What if newly established hybrids are the consequence of the natural adaptation of species to climate changes? For instance, it is argued that rapidly melting Arctic sea ice is opening a window to many hybridizations that will threaten polar biodiversity (Kelly et al., 2010).

Also, should we consider site protection, i.e., conserving sites of sympatry among closely related species? For instance, the creation of microreserves in Valencia (Spain) (Laguna et al., 2004, 2016) averted the extinction of the hybrid Quercus $\times$ coutinhoi (Q. faginea $\times$ Q. robur) with four relevant populations being protected in situ. In fact, $Q \times$ coutinhoi was identified for protection in the Valencian Community (Spain) since it was considered the last genetic trace of $Q$. faginea found to be regionally extinct (Mateo et al., 2016). Conservation of mixed populations have also been suggested for Cyclamen in Corsica and Sardinia (Thompson et al., 2018; Thompson, 2020), as well as for Orchis in Italy (Cozzolino et al., 2006) and Centaurea in Spain (López-Pujol et al., 2012). Finally, from our point of view, a big ethical question is if we should slow down the evolutionary process when it is intensified or disturbed by human activities?

We call for studies that target these questions. We suggest analyzing hybrids given the biology and stability of the hybrid population, and to determine under which circumstances hybrids represent a threat to the conservation of parental species. Instead of focusing on the causes of hybridization as proposed in other studies, we suggest focusing on the consequences of hybridization to quantify its impact and the degree of threat to parental species. Conservation management staff, and policy makers should also be educated about these aspects, as they are crucial to minimizing 
and managing intentional introductions and translocations. Despite all pitfalls and challenges involving hybrid conservation, ignoring the potential role of hybridization in our management choices simply implies not considering evolutionary processes that led to our current biodiversity but also implementing biased environmental policies.

\section{DATA AVAILABILITY STATEMENT}

The original contributions presented in the study are included in the article/Supplementary Materials, further inquiries can be directed to the corresponding author/s.

\section{AUTHOR CONTRIBUTIONS}

IM and DD conceived and designed the study. All authors collected data, drafted the manuscript, and gave final approval for publication.

\section{REFERENCES}

Abbott, R., Albach, D., Ansell, S., Arntzen, J. W., Baird, S. J. E., Bierne, N., et al. (2013). Hybridization and speciation. J. Evol. Biol. 26, 229-246. doi: 10.1111/j. 1420-9101.2012.02599.x

Abbott, R. J., Brennan, A. C., James, J. K., Forbes, D. G., Hegarty, M. J., and Hiscock, S. J. (2009). Recent hybrid origin and invasion of the British Isles by a selfincompatible species, Oxford ragwort (Senecio squalidus L., Asteraceae). Biol. Invasions 11, 1145-1158. doi: 10.1007/s10530-008-9382-3

Abbott, R. J., Hegarty, M. J., Hiscock, S. J., and Brennan, A. C. (2010). Homoploid hybrid speciation in action. Taxon 59, 1375-1386. doi: 10.1002/tax.595005

Abbott, R. J., and Lowe, A. J. (2004). Origins, establishment and evolution of new polyploid species: senecio cambrensis and S. eboracensis in the British Isles. Biol. J. Linn. Soc. 82, 467-474. doi: 10.1111/j.1095-8312.2004.00333.x

Ainouche, M. L., Baumel, A., Salmon, A., and Yannic, G. (2003). Hybridization, polyploidy and speciation in Spartina (Poaceae). New Phytol. 161, 165-172. doi: 10.1046/j.1469-8137.2003.00926.x

Albertin, W., and Marullo, P. (2012). Polyploidy in fungi: evolution after whole-genome duplication. Proc. R. Soc. B Biol. Sci. doi: 10.1098/rspb.2012. 0434

Allendorf, F. W., Leary, R. F., Spruell, P., and Wenburg, J. K. (2001). The problems with hybrids: setting conservation guidelines. Trends Ecol. Evol. 16, 613-622. doi: 10.1016/S0169-5347(01)02290-X

Arnold, M. L. (2006). Evolution through Genetic Exchange, Evolution through Genetic Exchange. Oxford: Oxford University Press.

Ayres, D., Schierenbeck, K., and Ellstrand, N. (2009). Introduction to "ecological and evolutionary consequences after invaders hybridize." Biol. Invasions 11, 1087-1088. doi: 10.1007/s10530-008-9391-2

Carman, J. G. (1997). Asynchronous expression of duplicate genes in angiosperms may cause apomixis, bispory, tetraspory, and polyembryony. Biol. J. Linn. Soc. 61, 51-94. doi: 10.1111/j.1095-8312.1997.tb01778.x

Chan, C.-H., Ballantyne, K. N., Aikman, H., Daugherty, C. H., and Chambers, G. K. (2006). Conservation Genetics of the Forbes' Parakeet (Cyanoramphus forbesi) on Mangere Island, Chatham Islands. Wellington: Science \& Technical Publishing.

Charles, K. M., and Stehlik, I. (2020). Assisted species migration and hybridization to conserve cold-adapted plants under climate change. Conserv. Biol. 35, 559566. doi: 10.1111/cobi.13583

Clark, E. L., Javzansuren, M., Dulamtseren, S., Baillie, J. E. M., Batsaikhan, N., Samiya, R., et al. (2006). Mongolian Red List of Mammals. Regional Red List Series Vol. 1. London: Zoological Society of London.

COSEWIC (2008). Annual Report The Minister of the Environment The Canadian Endangered Species Conservation Council (CESCC). Ottawa: COSEWIC.

\section{FUNDING}

This research received funds from Fundação para a Ciência e a Tecnologia in the frame of the project UIDB/00329/2020 (cE3c), the research unit UIDB/00239/2020 (CEF) and a post-doctoral fellowship SFRH/BPD/100384/ 2014 (DD).

\section{ACKNOWLEDGMENTS}

The authors would like to thank the three reviewers for their comments on a previous version.

\section{SUPPLEMENTARY MATERIAL}

The Supplementary Material for this article can be found online at: https://www.frontiersin.org/articles/10.3389/fevo.2021. 637100/full\#supplementary-material

Cozzolino, S., Nardella, A. M., Impagliazzo, S., Widmer, A., and Lexer, C. (2006) Hybridization and conservation of Mediterranean orchids: should we protect the orchid hybrids or the orchid hybrid zones? Biol. Conserv. 129, 14-23. doi: 10.1016/j.biocon.2005.09.043

Dobzhansky, T. (1951). Genetics and the Origin of Species, 3rd Edn. New York, NY: Columbia University Press.

Ellstrand, N. C. (1992). Gene flow among seed plant populations. New For. 6, 241-256. doi: 10.1007/BF00120647

Erwin, A. (2017). Hybridizing law: a policy for hybridization under the endangered species act. SSRN Electron. J. 47:10615. doi: 10.2139/ssrn.2930418

Galbreath, G. J., Mordacq, J. C., and Weiler, F. H. (2006). Genetically solving a zoological mystery: was the kouprey (Bos sauveli) a feral hybrid? J. Zool. 270, 561-564. doi: 10.1111/j.1469-7998.2006.00188.x

Gramlich, S., Wagner, N. D., and Hörandl, E. (2018). RAD-seq reveals genetic structure of the F 2 -generation of natural willow hybrids (Salix L.) and a great potential for interspecific introgression. BMC Plant Biol. 18:317. doi: 10.1186/ s12870-018-1552-6

Grant, B. R., and Grant, P. (1998). "Hybridization and speciation in Darwin's finches: the role of sexual imprinting on a culturally transmitted trait," in Endless Forms: Species and Speciation, eds D. J. Howard and S. H. Berlocher (New York, NY: Oxford University Press), 404-422.

Gu, Z., Gu, L., Eils, R., Schlesner, M., and Brors, B. (2014). Circlize implements and enhances circular visualization in R. Bioinformatics 30, 2811-2812. doi: 10.1093/bioinformatics/btu393

Haig, S. M., and Allendorf, F. W. (2006). "Hybrids and policy," in The Endangered Species Act at Thirty: Conserving Biodiversity in Human-Dominated Landscapes, eds J. M. Scott, D. D. Goble, and F. Davis (Chicago: Island Press), 150-163.

Hayward, M. W., Child, M. F., Kerley, G. I. H., Lindsey, P. A., Somers, M. J., and Burns, B. (2015). Ambiguity in guideline definitions introduces assessor bias and influences consistency in IUCN Red List status assessments. Front. Ecol. Evol. 3:87. doi: 10.3389/fevo.2015.00087

Hegde, S. G., Nason, J. D., Clegg, J. M., and Ellstrand, N. C. (2006). The evolution of California's wild radish has resulted in the extinction of its progenitors. Evolution 60, 1187-1197. doi: 10.1111/j.0014-3820.2006.tb01197.x

Hojsgaard, D., and Hörandl, E. (2019). The rise of apomixis in natural plant populations. Front. Plant Sci. 10:358. doi: 10.3389/fpls.2019.00358

Irisarri, I., Singh, P., Koblmüller, S., Torres-Dowdall, J., Henning, F., Franchini, P., et al. (2018). Phylogenomics uncovers early hybridization and adaptive loci shaping the radiation of Lake Tanganyika cichlid fishes. Nat. Commun. 9:3159. doi: 10.1038/s41467-018-05479-9

IUCN (2020a). Standards and Petitions Committee, 2019. Guidelines for Using the IUCN Red List Categories and Criteria. Version 14. Prepared by the 
Standards and Petitions Committee. Available online at: http://www.iucnredlist. org/ (accessed July 2020)

IUCN (2020d). Threats Classification Scheme (Version 3.2) [WWW Document]. Available online at: https://www.iucnredlist.org/resources/threat-classificationscheme (accessed 10.8.20)

IUCN (2020c). The IUCN Red List of Threatened Species. Version 2020-2 [WWW Document]. Available online at: https://www.iucnredlist.org/ (accessed 10.10.20)

IUCN (2020b). Stresses Classification Scheme (Version 1.0) [WWW Document]. Available online at: https://www.iucnredlist.org/resources/stressesclassification-scheme (accessed 10.8.20)

Jackiw, R. N., Mandil, G., and Hager, H. A. (2015). A framework to guide the conservation of species hybrids based on ethical and ecological considerations. Conserv. Biol. 29, 1040-1051. doi: 10.1111/cobi.12526

Kelly, B. P., Whiteley, A., and Tallmon, D. (2010). The arctic melting pot. Nature 468:891. doi: 10.1038/468891a

King, S. R. B., Boyd, L., Zimmermann, W., and Kendall, B. E. (2015). Equus ferus (errata version published in 2016). The IUCN Red List of Threatened Species 2015:e.T41763A97204950. Available online at: https://dx.doi.org/10. 2305/IUCN.UK.2015-2.RLTS.T41763A45172856.en

Laguna, E., Deltoro, V. I., Pèrez-Botella, J., Pèrez-Rovira, P., Serra, L., Olivares, A., et al. (2004). The role of small reserves in plant conservation in a region of high diversity in eastern Spain. Biol. Conserv. 119, 421-426. doi: 10.1016/j.biocon. 2004.01.001

Laguna, E., Fos, S., Jiménez, J., and Volis, S. (2016). Role of micro-reserves in conservation of endemic, rare and endangered plants of the Valencian region (Eastern Spain). Isr. J. Plant Sci. 63, 320-332. doi: 10.1080/07929978.2016. 1256131

Levin, D. (2002). Hybridization and extinction. Am. Sci. 90:254. doi: 10.1511/2002. 3.254

López-Pujol, J., Garcia-Jacas, N., Susanna, A., and Vilatersana, R. (2012). Should we conserve pure species or hybrid species? Delimiting hybridization and introgression in the Iberian endemic Centaurea podospermifolia. Biol. Conserv. 152, 271-279. doi: 10.1016/j.biocon.2012.03.032

Lowe, A. J., and Abbott, R. J. (2004). Reproductive isolation of a new hybrid species, senecio eboracensis Abbott \& Lowe (Asteraceae). Heredity (Edinb.) 92, 386-395. doi: 10.1038/sj.hdy.6800432

Mallet, J. (2005). Hybridization as an invasion of the genome. Trends Ecol. Evol. 20, 229-237. doi: 10.1016/j.tree.2005.02.010

Mallet, J. (2008). Hybridization, ecological races and the nature of species: empirical evidence for the ease of speciation. Philos. Trans. R. Soc. B Biol. Sci. 363, 2971-2986. doi: 10.1098/rstb.2008.0081

Marques, I., Jürgens, A., Aguilar, J. F., and Feliner, G. N. (2016). Convergent recruitment of new pollinators is triggered by independent hybridization events in Narcissus. New Phytol. 210, 731-742. doi: 10.1111/nph.13805

Marques, I., Loureiro, J., Draper, D., Castro, M., and Castro, S. (2018). How much do we know about the frequency of hybridisation and polyploidy in the Mediterranean region? Plant Biol. 20, 21-37. doi: 10.1111/plb. 12639

Mateo, G., Crespo, M. B., and Laguna, E. (2016). Flora Valentina. Angiospermiae (III), Convolvulaceae-Juglandaceae. Valencia: Fundación de la Comunidad Valenciana para el Medio Ambiente.

Mavárez, J., Salazar, C. A., Bermingham, E., Salcedo, C., Jiggins, C. D., and Linares, M. (2006). Speciation by hybridization in Heliconius butterflies. Nature 441, 868-871. doi: 10.1038 /nature04738

Mayr, E. (1940). Speciation phenomena in birds. Am. Nat. 74, 249-278. doi: 10. $1086 / 280892$

Mayr, E. (1942). Systematics and the Origin of Species. New York, NY: Columbia University Press.

Moreno, J. C. (2008). Lista Roja 2008 de la Flora Vascular Española / 2008 Red List of Spanish Vascular Flora. Madrid: Dirección General de Medio Natural y Política Forestal (Ministerio de Medio Ambiente, y Medio Rural y Marino, y Sociedad Española de Biología de la Conservación de Plantas).

Nieto Feliner, G., Álvarez, I., Fuertes-Aguilar, J., Heuertz, M., Marques, I., Moharrek, F., et al. (2017). Is homoploid hybrid speciation that rare? An empiricist's view. Heredity (Edinb.) 118, 513-516. doi: 10.1038/hdy. 2017.7
O’Brien, S. J., and Mayr, E. (1991). Bureaucratic mischief: recognizing endangered species and subspecies. Science 251, 1187-1188. doi: 10.1126/science.251.49 98.1187

Owens, G. L., Baute, G. J., and Rieseberg, L. H. (2016). Revisiting a classic case of introgression: hybridization and gene flow in Californian sunflowers. Mol. Ecol. 25, 2630-2643. doi: $10.1111 / \mathrm{mec} .13569$

Piett, S., Hager, H. A., and Gerrard, C. (2015). Characteristics for evaluating the conservation value of species hybrids. Biodivers. Conserv. 24, 1931-1955. doi: 10.1007/s10531-015-0919-3

Pimm, S. L., Dollar, L., and Bass, O. L. (2006). The genetic rescue of the Florida panther. Anim. Conserv. 9, 115-122. doi: 10.1111/j.1469-1795.2005.00010.x

Quilodrán, C. S., Montoya-Burgos, J. I., and Currat, M. (2020). Harmonizing hybridization dissonance in conservation. Commun. Biol. 3:391. doi: 10.1038/ s42003-020-1116-9

Rhymer, J. M., and Simberloff, D. (1996). Extinction by hybridization and introgression. Annu. Rev. Ecol. Syst. 27, 83-109. doi: 10.1146/annurev.ecolsys. 27.1.83

Rieseberg, L. H. (1997). Hybrid origins of plant species. Annu. Rev. Ecol. Syst. 28, 359-389. doi: 10.1146/annurev.ecolsys.28.1.359

Rieseberg, L. H., and Carney, S. E. (1998). Plant hybridization. New Phytol. 140, 599-624. doi: 10.1046/j.1469-8137.1998.00315.x

SARA (2002). House Government Bill C-5, An Act Respecting the Protection of Wildlife Species at Risk in Canada. Available online at: https://laws-lois.justice. gc.ca/pdf/S-15.3.pdf (accessed 25 October 2020)

Soltis, P. S., and Soltis, D. E. (2009). The role of hybridization in plant speciation. Annu. Rev. Plant Biol. 60, 561-588. doi: 10.1146/annurev.arplant.043008. 092039

Stelkens, R. B., Brockhurst, M. A., Hurst, G. D. D., and Greig, D. (2014). Hybridization facilitates evolutionary rescue. Evol. Appl. 7, 1209-1217. doi: $10.1111 /$ eva.12214

Thompson, J. D. (2020). Plant Evolution in the Mediterranean, 2nd Edn. Oxford: Oxford University Press.

Thompson, J. D., Gaudeul, M., and Debussche, M. (2010). Conservation value of sites of hybridization in peripheral populations of rare plant species. Conserv. Biol. 24, 236-245. doi: 10.1111/j.1523-1739.2009.01304.x

Thompson, J. D., Gauthier, P., Papuga, G., Pons, V., Debussche, M., and Farris, E. (2018). The conservation significance of natural hybridisation in Mediterranean plants: from a case study on Cyclamen (Primulaceae) to a general perspective. Plant Biol. 20, 128-138. doi: 10.1111/plb.12595

Trouwborst, A. (2014). Exploring the legal status of wolf-dog hybrids and other dubious animals: international and EU law and the wildlife conservation problem of hybridization with domestic and alien species. Rev. Eur. Comp. Int. Environ. Law 23, 111-124. doi: 10.1111/reel.12052

Twyford, A. D., and Ennos, R. A. (2012). Next-generation hybridization and introgression. Heredity (Edinb.) 108, 179-189. doi: 10.1038/hdy.2011.68

US (1973). The Endangered Species Act of 1973. Available online: https://www.fws. gov/international/pdf/esa.pdf (accessed June 2020)

USFWS, and NOAA (1996). Federal register: endangered and threatened wildlife and plants; proposed policy and proposed rule on the treatment of intercrosses and intercross progeny (the Issue of "Hybridization"); request for public comment. Fed. Regist. 61, 4710-4713.

Vallejo-Marín, M., and Hiscock, S. J. (2016). Hybridization and hybrid speciation under global change. New Phytol. 211, 1170-1187. doi: 10.1111/nph.14004

Yakimowski, S. B., and Rieseberg, L. H. (2014). The role of homoploid hybridization in evolution: a century of studies synthesizing genetics and ecology. Am. J. Bot. 101, 1247-1258. doi: 10.3732/ajb.1400201

Conflict of Interest: The authors declare that the research was conducted in the absence of any commercial or financial relationships that could be construed as a potential conflict of interest.

Copyright (C) 2021 Draper, Laguna and Marques. This is an open-access article distributed under the terms of the Creative Commons Attribution License (CC BY). The use, distribution or reproduction in other forums is permitted, provided the original author(s) and the copyright owner(s) are credited and that the original publication in this journal is cited, in accordance with accepted academic practice. No use, distribution or reproduction is permitted which does not comply with these terms. 